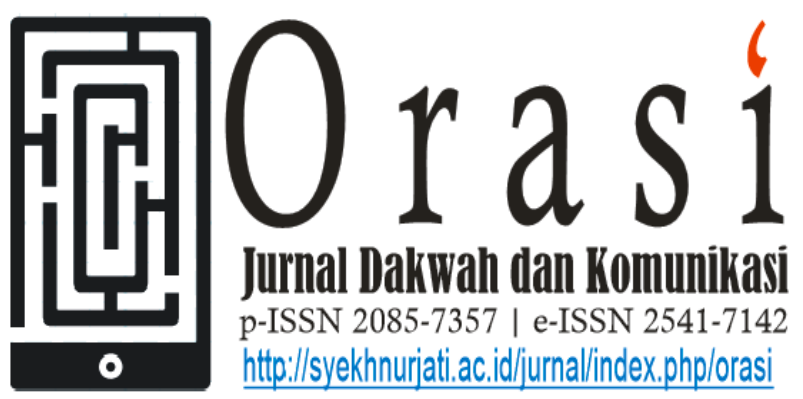

Volume 12 No. 2 Desember 2021

\title{
DISTORSI BAHASA KOMUNIKASI POLITIK JOKOWI MENGENAI PEMBANGUNAN PAPUA
}

\section{DISTORTION OF JOKOWI'S POLITICAL COMMUNICATION LANGUAGE REGARDING PAPUA DEVELOPMENT}

\author{
Hanifah Islamiyah ${ }^{1}$, Muzaki $^{2}$ \\ ${ }^{1}$ Jurusan Komunikasi dan Penyiaran Islam IAI Bunga Bangsa Cirebon \\ ${ }^{2}$ Jurusan Bimbingan dan Konseling Islam IAIN Syekh Nurjati Cirebon \\ a)e-mail: hanifah95islamiyah@gmail.com \\ b)e-mail:muzaki@syekhnurjati.ac.id
}

\begin{abstract}
ABSTRAK
Pemimpin politik kerap menggunakan penuturan bahasa untuk melindungi kekuasaannya. Distorsi bahasa dalam komunikasi politik dirumuskan oleh Mochtar Pabottingi yakni distorsi bahasa sebagai topeng, distorsi bahasa sebagai proyek lupa, distorsi bahasa sebagai representasi, dan distorsi bahasa sebagai ideologi. Bahayanya distorsi bahasa dengan tujuan menguatkan kekuasaan Jokowi dapat menjadikan negara yang totalitarianisme. Penelitian ini hendak mengetahui distorsi dalam penggunaan bahasa sebagai komunikasi politik yang dilakukan oleh Jokowi mengenai pembangunan infrastruktur di Papua. Penelitian ini merupakan penelitian deksriptif, yakni menganalisis bahasa yang memiliki fungsi yang bermacam-macam ketika dikomunikasikan, utamanya dalam menyampaikan ideologi program kepemimpinannya. Hasilnya adalah Jokowi menggunakan distorsi bahasa sebagai topeng untuk menarasikan Papua dikesampingkan, distorsi bahasa sebagai representasi untuk menggambarkan kondisi Papua tidak seperti yang sebenarnya, distorsi bahasa sebagai proyek lupa untuk melupakan aspek antropologis suku Papua, dan distorsi bahasa sebagai ideologi agar dapat dipahami dan menjadi maklum atas segala dampak yang diakibatkan daripada hal itu serta sila ke-lima Pancasila landasan pembangunan Jokowi.
\end{abstract}

Kata Kunci: Komunikasi Politik, Distorsi Bahasa, Jokowi, Papua.

\section{ABSTRACT}

Political leaders often use language to protect their power. Language distortion in political communication was formulated by Mochtar Pabottingi. He mentions 
language distortion as a mask, language distortion as a forgetting project, language distortion as representation, and language distortion as an ideology. The danger of language distortion to strengthen Jokowi's power can transform the country into a country of totalitarianism. This study aims to find out the distortion in the use of language as political communication carried out by Jokowi regarding infrastructure development in Papua. This research is a descriptive study analyzing language that has various functions when communicated, mainly in conveying the ideology of the leadership program. The result shows that Jokowi used language distortion as a mask to narrate Papua which was put aside, language distortion as a representation to describe the condition of Papua not as it was, language distortion as a forgetting project to leave out the anthropological aspects of the Papuan ethnics, and language distortion as an ideology so that it could be understood and understandable for all the impacts followed.

Keywords: Political Communication, Language Distortion, Jokowi, Papua.

\section{Pendahuluan}

Proses politik di dalam negara demokrasi secara tegas mengupayakan lahirnya interaksi antar unsur kepentingan, yakni antara komunikator politik dengan khalayak. Politikus menghasilkan produk politik untuk rakyat, dan rakyat meresponnya dengan berbagai cara. Indonesia sebagai negara demokrasi menjunjung tinggi egaliter publik untuk menyuarakan kepentingannya, tidak hanya dengan cara yang pasif, tapi juga dengan cara yang aktif seperti menggunakan hak untuk berbicara dan hak mendapatkan informasi yang faktual. Oleh karena itu, komunikasi politik menjembatani antara politisi dengan publik untuk mencapai suatu tujuan bersama.

Menurut Nur Sofyan (Sofyan, 2014) bahasa penting untuk mengkonstruk eksistensi kekuasaan. Selain untuk menunjukkan keberhasilan kedudukan yang didapatkan berdasarkan proses politik, penggunaan bahasa sebagai alat komunikasi politik juga untuk memuluskan kebijakan agar diterima oleh publik. Menurut Setiawan dalam (Nasution,
2007), komunikasi politik adalah suatu proses komunikasi yang bertujuan untuk mendapatkan dukungan publik bagi kebijakan politik. Pejabat publik akan lebih mudah mensosialisasikan kebijakannya sekaligus menunjukkan kekuasaannya.

Komunikator politik berasal dari tiga komponen masyarakat, yakni elit politik, akademis, dan aktivis (Nimmo, 2010). Komunikator politik dari komponen elit politik memiliki tingkatan birokratis yang menunjukkan semakin tinggi jabatan maka semakin besar kekuatan kebijakan yang dibuat.

Ketika pembuat kebijakan yang duduk memimpin birokrasi politik tertinggi hendak melaksanakan program, maka ia membutuhkan dukungan publik. Saat memproduksi kebijakan tidak serta merta mendapat dukungan masyarakat, proses untuk memproduksi kebijakan akan melewati konflik. Banyak kemudian pembuat kebijakan menggunakan bahasa yang persuasif dalam narasi komunikasi politik yang disampaikan untuk menghindari konflik. 
Menurut Suparno (2014), setiap situasi mengandung isu yang dapat dilihat dalam tiga hal. Segi potensi, dalam konteks kebijakan politik, segi kontestasi, yakni konflik yang terjadi akibat adanya pihak-pihak yang bertentangan (clash of argument), dan segi akseptasi, yakni penerimaan atau persetujuan pihak-pihak terkait mengenai suatu bentuk kesepakatan (Suparno, 2014). Bahasa sebagai alat komunikasi politik digunakan untuk meraih segi akseptuasi.

Dalam kehidupan politik yang demokratis direncanakan program-program pembangunan, baik pembangunan infrastruktur maupun pembangunan manusia. Komunikasi politik dalam konteks pembangunan selalu menyangkut pengupayaan untuk menghilangkan potensi di dalam proses menjalankan kebijakan (Suparno, 2010). Sebisa mungkin program pembangunan tersebut tidak menemui rintangan dan halangan dalam perjalanannya, sehingga komunikasi politik yang efektif diperlukan dengan cara yang tepat.

Masa kepemimpinan Presiden Joko Widodo, atau lekat dipanggil Jokowi, pada periode 2014-2019 gencar melaksanakan program pembangunan infrastruktur di sejumlah wilayah.Utamanya pembangunan di daerah pedalaman, daerah perbatasan negara, dan di daerah timur Indonesia. Diantara pembangunan yang monumental adalah pembangunan Trans-Papua, jalan yang menghubungkan Kota Sorong di Provinsi Papua Barat sampai Kota Merauke di Provinsi
Papua, serta pembangunan lainnya semisal Jembatan Youtefa.

Jokowi dalam berbagai kesempatan di hadapan media dan masyarakat kerap menyampaikan rencana yang akan dilakukan dan hasil yang telah dicapai mengenai pembangunan infrastruktur di Papua. Tidak hanya dalam skala proyek pembangunan, tapi juga mengarah pada ideologi pembangunan yang menjadi fondasi Jokowi melaksanakan program kepemimpinannya. Ideologi pembangunan tidak selalu disebutkan dengan jelas, namun menggunakan narasi-narasi yang mengarahkan pikiran publik terhadap tujuantujuan pembangunan yang lebih ideologis.

Jokowi, dalam perbahasaannya mengenai pembangunan di Papua dan Papua Barat selalu menekankan bahwa pembangunan tersebut adalah kewajiban. Bahkan, program Jokowi yang paling besar pada masa kepemimpinannya berada pada pembangunan infrastruktur di Papua. Jokowi terus menerus mendorong, bahkan ketika terjadi penyerangan Organisasi Papua Merdeka (OPM) memakan korban jiwa pekerja pembangunan, TransPapua dan pembangunan lainnya harus tetap dilanjutkan.

Sebagaimana semestinya bahasa, hakikatnya netral, tidak ada bahasa yang bernilai baik atau buruk. Bahasa adalah sistem isyarat yang mengantarkan penuturnya mencapai tujuan baik maupun buruk. Bahasa menyiapkan frasa-frasa, klausa-klausa, dan kalimat-kalimat untuk menggambarkan objek. Bahasa hanya akan bermakna apabila dibatasi oleh penutur (Nasution, 2007). 
Pemimpin politik kerap menggunakan penuturan bahasa untuk melindungi kekuasaannya, mendominasi alam berpikir masyarakatnya untuk masuk ke dalam bingkai pemahamannya, dalam perencanaan yang baik maupun buruk. Distorsi bahasa dalam komunikasi politik pertama kali dirumuskan oleh Mochtar Pabottingi yang kemudian dikenal dengan empat distorsi bahasa dalam komunikasi politik. Ada empat distorsi bahasa dalam komunikasi politik menurut Pabottingi dalam (Nasution, 2007), yakni distorsi bahasa sebagai topeng, distorsi bahasa sebagai proyek lupa, distorsi bahasa sebagai representasi, dan distorsi bahasa sebagai ideologi. Penguasa yang menggunakan distorsi bahasa dalam komunikasi politik untuk melancarkan programnya dengan tolok ukur keberhasilan bingkai pemikirannya.

Fenomena yang sama pernah terjadi pada era kepemimpinan Soeharto. Narasi yang disampaikan Soeharto pada masa kepemimpinannya dalam mengenalkan proyek pembangunan adalah dengan eufemisme bahasa. Karena pembangunan pada Orde Baru lebih berpusat pada aspek ekonomi, muncullah jargon-jargon ekonomi seperti "akselerasi", "tinggal landas", "efisiensi", "pertumbuhan", "teknologi", "modernisasi", dan sebagainya (Latif et al., 1996). Jargon yang dibuat merupakan komunikasi politik Soeharto untuk memberikan pesan bahwa pembangunan bermakna peningkatan, kemajuan, praktis, menujukkan perkembangan, mengikuti perkembangan zaman, dan sudah seharusnya terjadi.
Dari cara perbahasaan Soeharto melanggengkan kekuasaannya, ia telah menciptakan negara yang totalitarianisme. Orde baru mengalami kondisi terburuk yang pernah terjadi oleh bangsa Indonesia yang merdeka. Krisis ekonomi, gerakan separatis, kerusuhan politik, dan percobaan kudeta yang memakan korban tidak dapat terhindarkan di akhir kepemimpinannya (Yunida Nur, 2019).

Eufemisme dan jenis distorsi bahasa lainnya dengan tujuan menguatkan kekuasaan untuk menjalankan semua instrumen pembangunan dapat terjadi di era Jokowi apabila terus ia gunakan. Oleh karena itu, penelitian ini hendak mengetahui distorsi dalam penggunaan bahasa sebagai komunikasi politik yang dilakukan oleh Jokowi mengenai pembangunan infrastruktur yang ia lakukan di Papua. Pertanyaan penelitiannya adalah bagaimana penggunaan distorsi bahasa dalam komunikasi politik yang digunakan Jokowi melancarkan pembangunan Papua? Dan apa ideologi pembangunan Jokowi berdasarkan narasi yang disampaikan mengenai pembangunan di Papua?

Bahasa yang digunakan dalam menarasikan pembangunan atau komunikasi politik pembangunan Jokowi penting untuk diteliti agar mengetahui ideologi pembangunan dan simbol dalam penggunaan bahasa yang digunakan oleh Jokowi .

\subsection{Penelitian Terdahulu}

Penelitian relevan yang telah dilakukan oleh Zahri Nasution (2007) dengan judul penelitian "Bahasa sebagai Alat Komunikasi Politik dalam Rangka Mempertahankan Kekuasaan" yang diterbitkan 
oleh Sodality: Jurnal Transdisiplin Sosiologis, Komunikasi dan Ekologi Manusia edisi Desember 2007. Nasution menyebutkan, bahasa adalah kekuatan dan sangat berperan dalam mencapai tujuan nasional maupun internasional. Apabila bahasa digunakan secara superintensif termasuk di dalamnya penyalahgunaan (abuse) bahasa dan menjadi produk pertarungan dan rekayasa politik pada era Orde Baru. Hasil penelitiannya adalah distorsi bahasa yang digunakan sebagai komunikasi politik Soeharto adalah bahasa sebagai topeng, bahasa sebagai proyek lupa, bahasa sebagai representasi, dan bahasa sebagai ideologi. Distorsi bahasa yang dilakukan bertujuan agar kekuasaan yang dimiliki oleh penguasa tetap dapat bertahan

\subsection{Teori Distorsi Bahasa}

Distorsi bahasa dalam komunikasi politik pertama kali dirumuskan oleh Mochtar Pabottingi yang kemudian dikenal dengan empat distorsi bahasa dalam komunikasi politik. Ada empat distorsi bahasa dalam komunikasi politik menurut Pabottingi dalam (Nasution, 2007), yakni distorsi bahasa sebagai topeng, distorsi bahasa sebagai proyek lupa, distorsi bahasa sebagai representasi, dan distorsi bahasa sebagai ideologi. Penguasa yang menggunakan distorsi bahasa dalam komunikasi politik untuk melancarkan programnya dengan tolok ukur keberhasilan bingkai pemikirannya.

\section{Metodologi Penelitian}

Penelitian ini merupakan penelitian deksriptif, yakni peneliti mengembangkan konsep dan menghimpun fakta-fakta, bukan menguji hipotesis. Menurut Vredenbregt dalam (Rakhmat dan Ibrahim, 2015) jenis penelitian deskriptif adalah jenis penelitian yang terpisah dari jenis penelitian yang lain. Penelitian deskriptif bertujuan untuk mendeskripsikan segala hal yang berkaitan dengan objek penelitian. Metode penelitian deskriptif juga dapat diartikan sebagai penelitian yang menghasilkan data deskriptif mengenai kata- kata lisan maupun tertulis, dan tingkah laku yang dapat diamati (Rakhmat dan Ibrahim, 2015).

Di dalamnya juga terdapat upaya mendeskripsiskan, mencatat, analisis dan menginterpretasikan kondisi yang sekarang ini terjadi. Penelitian ini bertujuan untuk memberikan pemahaman mengenai bahasa yang memiliki fungsi yang bermacam-macam ketika dikomunikasikan, utamanya dalam menyampaikan ideologi program kepemimpinannya (Rakhmat dan Ibrahim, 2015). Penelitian kualitatif ini dilakukan untuk mengetahui perilaku, motivasi, tindakan, persepsi, dan aspek holistik lainnya mengenai seseorang. Dan penelitian ini dilakukan dengan cara mendeskripsikan menggunakan konteks khusus yang alamiah dan memanfaatkan berbagai metode (Moleong, 2017).

Peneliti akan menganalisa narasi yang pernah disampaikan oleh Jokowi melalui saluran Youtube Kementerian Sekretariat Negara RI dengan judul "Temu Kangen Masyarakat Indonesia di Selandia Baru” yang diunggah pada tanggal 22 Maret 2018, sedangkan acaranya sendiri berlangsung di Wellington pada tanggal 19 Maret 2018, dan 
juga saluran Youtube Presiden Joko Widodo dengan judul "Jembatan Holtekamp di Teluk Youtefa" yang diunggah pada tanggal 12 April 2018. Hasil dari analisa yang didapatkan akan disimpulkan menggunakan penjelasan dalam bentuk kata-kata dan bahasa. Peneliti mengembangkan konsep dan menghimpun fakta-fakta, bukan menguji hipotesis.

Metode penelitian deskriptif juga dapat diartikan sebagai penelitian yang menghasilkan data deskriptif mengenai katakata lisan maupun tertulis, dan tingkah laku yang dapat diamati. Di dalamnya juga terdapat upaya mendeskripsikan, mencatat, analisis dan menginterpretasikan kondisi yang sekarang ini terjadi. Penelitian ini bertujuan untuk memberikan pemahaman mengenai bahasa yang memiliki fungsi yang bermacam-macam ketika dikomunikasikan, utamanya dalam menyampaikan ideologi program kepemimpinannya. (Rakhmat dan Ibrahim, 2015)

\section{Hasil dan Pembahasan}

\subsection{Kabupaten Nduga dalam Narasi Jokowi}

Nduga adalah salah satu kabupaten di pesisir Provinsi Papua yang menghubungkan ke 11 kabupaten lainnya yang berada di pegunungan tengah Provinsi Papua. Kondisinya yang berada di tengah hutan menjadikan jalur di Distrik Yigi menjadi jalur yang dilalui oleh kelompok bersenjata. Hal itu juga mengakibatkan seringnya terjadi gangguan keamanan dari kelompok bersenjata di Papua .
Meski Kabupaten Nduga ini berstatus zona merah, namun Kabupaten Nduga merupakan titik strategis untuk membuka jalan kabupaten lainnya. Agar terdapat akses jalan kendaraan, sejumlah pembangunan infrastruktur seperti jembatan dan jalan TransPapua melalui jalur Kabupaten Nduga.

Sebelum dilaksanakannya pembangunan, Jokowi sempat mengunjungi Kabupaten Nduga berdasarkan saran salah seorang warga kepadanya. Hal itu disampaikan oleh Jokowi saat sesi tanya-jawab pada saat kunjungannya ke Selandia baru.

Jokowi melalui saluran Youtube Kementerian Sekretariat Negara RI dengan judul "Temu Kangen Masyarakat Indonesia di Selandia Baru" menyinggung soal pembangunannya di Papua.Video yang berdurasi 15 menit 42 detik tersebut menunjukkan salah seorang warga Indonesia bernama Fransiskus Orlando yang berasal dari Kota Timika. Ia merupakan seorang mahasiswa dari salah satu perguruan tinggi di Selandia baru. Ia mengajukan pertanyaan mengenai motivasi Jokowi sering mengunjungi Papua dan Papua Barat.

Pertanyaan tersebut dijawab oleh Jokowi;

“.. 2014 akhir, satu setengah bulan setelah saya dilantik, saya langsung terbang ke (pulau) Papua. Saya betul-betul ingin mendengar secara langsung kondisi, baik masyarakat, baik infrastrukturnya, baik fasilitas-fasilitas yang ada di sana, dibandingkan wilayah-wilayah lain. Karena dari studi yang dilakukan oleh Bappenas, memang Indonesia bagian Timur ini ... lama di... apa ya, istilahnya ... dilupakan, -dianaktirikan? Ya..atau diabaikan. Dianaktirikan kok kejem banget.Ya, kira-kira 
itu, jadi wilayah timur ini kurang kita perhatikan. Baik di pembangunan infrastruktur, pembangunan sumber daya manusia, semuanya. Dan informasi yang saya terima, data yang saya terima, ingin saya lihat lapangannya seperti apa. Dan ternyata betul, tadi salah satunya, jalan, misalnya di antar-kabupaten saja tidak ada. Kemudian saya saat enam bulan setelah itu saya pergi ke Papua lagi, saya sekarang ini sudah tujuh kali datang ke Papua. Dan itu merupakan provinsi yang paling sering saya kunjungi.Padahal kalau mau terbang dari Jakarta ke Papua itu butuh waktu 6 jam.Tapi ya memang ini adalah wilayah Negara Kesatuan Republik Indonesia yang harus kita perhatikan”.

Perbahasaan yang digunakan dalam Jokowi untuk menjawab motivasi yang mendorongnya untuk berkunjung dan membangun Papua mengandung beberapa poin. Jokowi mengungkapkan alasan ia langsung mengunjungi Papua pada satu setengah bulan pertama kepemimpinannya. Ia mengungkapkan bahwa selama ini Papua "dilupakan" dan "diabaikan", kalimat eufemisme dari tawaran publik untuk menggunakan istilah "dianak-tirikan". Jokowi menyebutkan bahwa "dianak-tirikan" memiliki kesan "kejem/kejam". Eufemisme adalah ungkapan yang lebih halus sebagai pengganti ungkapan yang dirasakan kasar (KBBI, website).

Menurut Allan dan Burridge (1991), eufemisme digunakan untuk menutupi suatu hal, baik natural maupun tidak, yang tidak disukai oleh penutur untuk menutupi ketidaksukaan atau kemurkaan. Jokowi menghaluskan kata "dianak-tirikan" bukan untuk menghaluskan kondisi Papua yang sebenarnya, melainkan, sebagai kalimat pembuka untuk menjawab pertanyaan ini. Kata Papua "diabaikan" dan "dilupakan" hendak menunjukkan sudut pandang Jokowi dalam melihat segala aspek Papua. Dengan menggunakan kedua kata tersebut, Jokowi membentuk gagasan awal audience untuk dapat membayangkan posisi awal Papua terlebih dahulu dan apa yang akan diucapkan selanjutnya adalah penjelasan dari kondisi “diabaikan" dan "dilupakan".

Pengaruh bahasa eufemisme lebih besar apabila digunakan dalam komunikasi politik. Mengindahkan bahasa menjadi tidak benar apabila digunakan dalam narasi politik karena menyangkut kepentingan dan pengetahuan publik. Eufemisme masuk ke dalam kategori distorsi bahasa sebagai topeng. Apabila narasi "Papua -telahdikesampingkan" disampaikan oleh seorang Presiden, maka pemahaman itu juga akan menjadi pemahaman negara. Dan pemahaman negara akan daerahnya sebagai bagian yang telah "diabaikan" dan "dilupakan”, akan menciptakan pemahaman publik secara luas, baik warga negara Indonesia maupun internasional, bahwa selama ini negara telah meng-“abaikan" dan me-“lupakan" Papua.

Hal ini diperkuat oleh Budi Hernawan (Hernawan.-), pendekatan Jokowi yang develop mentalistik menguatkan stigma terhadap Papua dan menempatkannya dalam "Perkecualian". Setelah melekatkan citra primitif, Jokowi sebagai presiden justru menggunakan privilegenya menggunakan media massa untuk mereproduksi stigma dan citra tersebut lebih luas. Akibatnya khalayak 
ramai mempercayai stigma tersebut sebagai kebenaran faktual dan menganggap wajar keterbelakangan Papua serta konsekuensi memberlakukan hukum yang lebih opresif (Hernawan, - ).

Posisi "diabaikan" dan "dilupakan" yang diungkapkan oleh Jokowi menyudutkan pemerintahan sebelumnya. Narasinya juga menunjukkan bahwa pemerintah sebelumnya tidak memperhatikan Papua -tidak seperti dirinya. Tidak hanya itu, dengan menekankan kalimat “...saya sekarang ini sudah tujuh kali datang ke Papua. Dan itu merupakan provinsi yang paling sering saya kunjungi. Padahal kalau mau terbang dari Jakarta ke Papua itu butuh waktu 6 jam. Tapi ya memang ini adalah wilayah Negara Kesatuan Republik Indonesia yang harus kita perhatikan". Jokowi menunjukkan bahwa ia pemimpin yang memberikan perhatian pada Papua.

"Saat saya di Papua, saya pingin sekali ke kabupaten yang namanya Nduga.Karena ada informasi yang datang ke saya, 'pak, bapak, harus datang ke Nduga. Bapak nanti akan kaget'.'loh kenapa kaget?', 'ya bapak pergi saja'. Terus saya minta, saya perintah saat itu, 'saya mau ke Nduga, saya mau ke Kabupaten Nduga'. Oleh Kapolri, oleh Panglima saat itu, saya tidak diperbolehkan, 'bapak jangan ke sana. Karena itu daerah berbahaya. Daerah rawan. Daerah yang paling rawan'.Saya sampaikan saat itu, saya ingat betul. 'saya gak mau tahu', saya perintah pada Panglima dan Kapolri, 'saya gak mau tahu, pokoknya dua hari lagi saya akan ke Nduga. Urusan keamanan itu urusanmu'. Saya mau terbang ke sana. Betul, saya terbang ke sana naik helikopter karena emang gak ada jalur daratnya. Saya naik heli, saya ke Jayapura, dari Jayapura ke Wamena, dari Wamena baru naik heli ke Nduga. Saya yakin tadi, siapa, yang dari Papua tadi? Orlando? Mana Orlando tadi?Orlando mana?Pernah ke Nduga?Ngaku aja, pernah ke Nduga? Nah, belum kan. Belum pernah, ya karena memang dari Wamena saja mau ke Nduga butuh waktu 4 hari berjalan di tengah hutan. 4 hari 4 malam. Kalau bilang sudah, saya cek bener. Untungnya bilangnya belum.Dan saya percaya.Setelah saya sampai di Nduga, saya kesana dengan bu Jokowi, naik heli begitu turun di Nduga ketemu Pak Bupati. Saya melihat, itu di kotanya, kantor Kabupaten Nduga ada disitu, saya lihat kok gak ada orang, satu orang pun. Di tengah hutan, ada wilayahnya, saya tanya ke Bupati, 'penduduknya disini ada berapa?', pak Bupati menyampaikan ke saya, "pak presiden, disini ada -saya inget, 129.000'. Mana, satu aja gak ada. 'bener ada?', 'betul pak. Itu, distriknya ada di tengah-tengah hutan, pak. Kalau bapak mau ngecek silahkan'. Pak bupati ini pinter, pasti saya gak ngecek. 'Kira-kira berjalan dari sini ada yang 8 jam, ada yang 12 jam', ya dia udah nyangka saya ga akan mungkin jalan. Oke, saya percaya. Tapi yang perlu saya sampaikan disini adalah, di kabupaten Nduga ini aspal satu meter saja tidak ada. Ini lah yang menyebabkan saya sedih sekali, dan saat itu saya perintahkan, agar jalan dari Wamena ke Nduga itu segera dibangun dan dikerjakan, dan tadi, saya sudah melihat hasilnya tadi."

Menurut Situs resmi Dinas Pariwisata Provinsi Papua, Nduga adalah salah satu Kabupaten di Provinsi Papua dengan ibukota 
Kenyam, yang sebelumnya pernah menjadi bagian dari wilayah administratif Kabupaten Jayawijaya. Kabupaten ini di bentuk pada tanggal 4 Januari 2008 berdasarkan UU Nomor 6 Tahun 2008 bersama-sama dengan pembentukan 5 Kabupaten lainnya di Papua.

Kabupaten Nduga mempunyai luas wilayah $2.168 \mathrm{~km} 2$ dan batas wilayahnya adalah : sebelah Barat berbatasan dengan Distrik Jila, sebelah Timur berbatasan dengan Distrik Pelebaga dan Wamena, Sebelah Utara berbatasan dengan Distrik Kuyawage, Distrik Balingga, Distrik Pirime dan Makki, sebelah Selatan berbatasan dengan Sawaerma, Asmat. Kabupaten Nduga terbagi dalam 36 desa dan 8 Distrik diantaranya : Distrik Wosak, Distrik Kenyam, Distrik Geselma, Distrik Mapenduma, Distrik Mugi, Distrik Yigi, Distrik Mbua, Distrik Gearek .

Jokowi sempat menyinggung ucapan Kepala Kepolisian RI atau Kapolri dan Panglima TNI yang menyebut bahwa Kabupaten Nduga adalah "daerah rawan" dan "daerah berbahaya". Namun, tidak dijelaskan selanjutnya makna "rawan" dan "berbahaya" yang dimaksud. Tidak Jokowi jelaskan juga kondisi "rawan" dan berbahaya" itu bagi siapa, apakah berbahaya bagi semua kalangan ataukah bagi dirinya sendiri sebagai presiden. Apabila yang ia maksud "rawan" dan "berbahaya" dikarenakan Nduga merupakan basis bagi Organisasi Papua Merdeka (OPM), keterangan ini bertentangan dengan liputan seorang jurnalis dalam buku Jim Elmslie yang berjudul Irian Jaya Under the Gun: Indonesian Economic Development versus West Papuans Nationalism.
Ben Bohane, seorang jurnalis yang melakukan perjalanan di Nduga menyatakan bahwa anggota OPM berbaur bersama masyarakat sipil. Hal yang membedakan anggota OPM dan masyarakat sipil hanyalah motivasi melepaskan Papua dari Indonesia. Sedangkan secara pandangan hukum adat, anggota OPM dan masyarakat sama-sama memegang teguh dan menjalankan kehidupan dalam rajut kebudayaan Papua (Elmslie, 2002).

Kata "rawan" dan "berbahaya" yang disampaikan Jokowi yang dirujuk dari Kapolri dan Panglima dalam konteks komunikasi politik dapat bermakna distorsi bahasa sebagai representasi. Menurut Pabottingi dalam (Nasution, 2007), kegagalan komunikan memahami maksud komunikator bisa terjadi apabila terjadi distorsi bahasa yang menggambarkan tidak sebagaimana mestinya keadaan. Penggambaran yang tidak sesuai merupakan tindakan yang berbahaya. Penggamabaran yang buruk akan suatu hal yang tidak seperti kenyataannya adalah senjata simbolik untuk menghancurkan objek, dengan membangkitkan kebencian serta mengesahkan untuk melalukukan pembantaian dan penghancuran, dalam konteks ini adalah OPM dan hal yang membuat Nduga menjadi "rawan" dan "berbahaya".

Penjelasan selanjutnya, Jokowi menggambarkan perjalanan yang harus dilalui untuk sampai ke Nduga. Jokowi kemudian memberikan narasi dalam penggambarannya mengenai Nduga dengan kalimat, “..., di kabupaten Nduga ini aspal satu meter saja tidak ada. Ini lah yang menyebabkan saya 
sedih sekali, ...". Jokowi membangun apa yang disebut oleh Nasution (2007) dengan bahasa sebagai proyek lupa. Bahasa sebagai proyek lupa dalam kaitannya dengan komunikasi politik ketika komunikator mengajak gagasan komunikan dalam keadaan lupa, dengan sengaja menghilangkan dan mengecilkan aspek lainnya yang bagi komunikator hendak dianggap tidak penting.

Sebagian besar masyarakat Papua memiliki pandangan tersendiri mengenai alam, Tuhan, dan roh. Tanah adalah tempat berlangsungnya kehidupan turun temurun. Dalam eko-budaya suku etnik asli Papua, tidak ada kawasan lingkungan Papua yang masuk dalam kategori tidak bertuan setiap jengkal tanah memiliki ikatan budaya dengan masyarakat mengenai adat istiadat dalam setiap langkah kakinya (Erari, 2000). Artinya, apabila konstruk pemikiran Jokowi sebagai penguasa dipaksakan dalam pemikiran suku Nduga, penduduk asli Kabupaten Nduga, maka makna yang terbentuk adalah perebutan atas kepemilikan tanah yang mengandung budaya dan kearifan lokal lainnya. Tidak adanya aspal adalah yang menjadi kehendak suku Nduga sebagai penghuni kawasan, dan seharusnya tidak memberikan kesan "sedih" bagi siapapun, sekalipun kepada presiden.

Perbahasaan Jokowi yang mengandung distorsi bahasa sebagai proyek lupa, menjadikan narasi bahwa Papua dan suku yang hidup di dalamnya tidak hanya memiliki tanah sebagaimana secara bentuk, tapi juga memiliki aspek-aspek lain yang tidak dijadikan Jokowi sebagai bahan pertimbangan pembangunan. Jokowi melupakan, membuat publik lupa, bahkan ingin membuat suku Papua sendiri lupa unsur antropologis di tanah Papua. Pembangunan infrastuktur harus dibangun di atas segala kepentingan yang lain. "untuk membuka isolasi saudarasaudara kita yang ada di sana. Membuka dulu. Sebagian sudah diaspal, sebagian belum. Tapi paling tidak, kendaraan bisa lewat, mobil bisa lewat, motor trail juga bisa sampai ke sana. Itu. Dan sekarang, 4-6 jam lah dari Wamena ke Nduga sudah bisa dilalui. Saya sudah nyoba separonya. Saat itu juga saya minta ke pak Bupati. 'pak Bupati, ini bener ada 129.000 gak sih penduduk yang ada di sini?', 'bener pak, ada', 'oke, saya tunjukkan saja, tempat yang paling ramai yang ada di kabupaten ini dimana,', ‘bisa pak, kita ke pasar'. Saya diajak ke pasar.Begitu sampai di pasar, saya kaget. Ternyata disitu juga ada, paling-paling, 60 orang-an saja. 60. Bukan 60.000. 60 orang. Inilah kondisi apa adanya yang ingin saya sampaikan kepada bapak-ibu dan saudarasaudara semuanya. Berkaitan dengan pertanyaan tadi, kenapa saya begitu intens ke Papua, dorongan apa yang menyebabkan, ya jawabannya itu. Semakin saya tahu, semakin saya ingin memberikan perhatian yang berbeda kepada Papua.”

Jokowi menggunakan kata "isolasi" untuk menggambarkan secara umum posisi geografis Kabupaten Nduga. Isolasi bermakna pemisahan suatu hal dari hal lain atau usaha untuk memencilkan manusia dari manusia lain; pengasingan; pe-mencilan; pengucilan; Keadaan terpencilnya satu wilayah karena jauh dari hubungan lalu lintas; Penyekatan (pengham-batan atau penahanan arus listrik 
oleh suatu bahan sehingga arus itu tidak dapat mengalir (KBBI, website).

Padahal, posisi geografis Kabupaten Nduga yang digambarkan antar distrik ada di tengah-tengah hutan menunjukkan bahwa kondisi tersebut bukan dikarenakan "pemisahan dari hal lain", tidak ada "usaha untuk memencilkan manusia dan manusia lain", tidak ada "pengasingan", tidak ada bentuk "pemencilan" dan "pengucilan" yang dilakukan oleh pihak lain terhadap Kabupaten Nduga, melainkan karena kondisi alami. Bahkan, suku Nduga hidup dari hasil bumi di hutan, jadi hutan adalah bagian dari kehidupan Kabupaten Nduga yang tidak bisa dipisahkan.

\subsection{Ideologi Pembangunan Jokowi dalam Narasi Peresmian Jembatan Holtekamp}

Pada video dengan judul "Jembatan Holtekamp di Teluk Youtefa" menunjukkan proses pembangunan jembatan warna merah tersebut. Dengan mengilustrasikan pembangunan, ditampilkan testimoni dari beberapa masyarakat sipil yang mengutarakan kepuasan pembangunan yang dilakukan Jokowi lengkap dengan ucapan terimakasih. Pada dua menit terakhir, Jokowi memberikan sambutan. Berikut narasi yang diungkapkan Jokowi:

"tanah air kita terbentang luas dari barat ke timur. Berjajar puluhan ribu pulau yang mempersatukan lautan dengan keindahan alam, kekayaan alam, dan keragaman budaya yang menakjubkan. Dengan kondisi geografis yang sangat menantang, negara sedang berjuang dan akan terus berjuang agar pemerataan pembangunan bisa terlaksana dari Sabang sampai Merauke, dari Miangas sampai pulau Rote. Sebuah tugas yang besar dan menantang tapi keadilan sosial adalah sebuah panggilan, adalah kewajiban yang harus dihadirkan negara. Saya berada di sini, di tanah papua, mari kita menyincingkan lengan bersama karena Papua adalah Indonesia, karena kita adalah satu saudara. Matahari selalu terbit dari timur, dan papua adalah cahaya di timur Indonesia."

Video berdurasi 3 menit 12 detik tersebut mengandung ideologi pembangunan Jokowi, khususnya pembangunan Jokowi di Papua. Jokowi menggunakan kata “pemerataan pembangunan”. Frasa "pemerataan pembangunan" bertentangan dengan kalimat sebelumnya yang menjelaskan bahwa Indonesia adalah “...lautan dengan keindahan alam, kekayaan alam, dan keragaman budaya yang menakjubkan. Melihat kebutuhan primer masyarakat adat suku Papua terhadap sumber daya alam menunjukkan bahwa “... keindahan alam, kekayaan alam, dan keragaman budaya" tidak dapat disamaratakan dengan pembangunan dari "Sabang sampai Merauke, dari Miangas sampai Pulau Rote" yang memiliki keragaman budaya yang berbeda. Pengahayatan terhadap alam dan budaya masing-masing masyarakat adat dan kesukuan berbeda. Pembangunan infrastruktur yang justru merusak kearifan lokal setempat tidak sesuai dengan kekayaan alam yang merupakan bagian dari keragaman budaya yang menakjubkan bagi suku Papua.

Ideologi pembangunan Jokowi juga tertuang pada kalimat Jokowi selanjutnya yang berbunyi "Sebuah tugas yang besar dan menantang tapi keadilan sosial adalah sebuah 
panggilan, adalah kewajiban yang harus dihadirkan negara." Sila ke-lima Pancasila dikutip dalam landasan pembangunan Jokowi dijadikan sebagai ideologi pembangunan. John Rawls memandang keadilan sosial lebih unggul atas teori utilitarianisme, keadilan dilihat apabila memaksimalkan keuntungan dan kegunaan, menggunakan pertimbangan moral etis atas keadilan sosial (Tarigan, 2018). Keadilan sosial yang dimaknai Jokowi menggunakan perspektif utilitarianisme yang membuat "rata-rata" atau average utulitarianisme dengan memaksimalkan keuntungan rata-rata perkapita.

Dewantoro dalam (Sumarno, 2017) menjelaskan bahwa kesejahteraan sosial yang dimaksud Soekarno adalah kemakmuran yang harus dinikmati oleh segenap warga bangsa Indonesia, karena untuk kepentingan inilah sebuah bangsa terbentuk.

Distorsi bahasa dalam narasi Jokowi di video "Jembatan Holtekamp di Teluk Youtefa" merupakan distorsi bahasa sebagai ideologi. Ideologi pada dasarnya bersifat distorsif, dan distorsi bahasa sebagai ideologi menghendaki narasi distorsi bahasa yang lain (Nasution, 2007). Tujuan dari sifat distorsif dalam mengkomunikasikan ideologi untuk mengidentikkan kegiatan politik sebagai kemampuan politik seorang pemimpin negara dan menawarkan suatu sistem (program) politik tertinggi.

Narasi yang disampaikan Jokowi pada video ini juga berbanding dengan narasi yang disampaikan Jokowi pada video "Temu Kangen Masyarakat Indonesia di Selandia Baru". Jokowi menggambarkan kondisi alam
Nduga yang masih natural dengan kondisi alam Indonesia secara menyeluruh sangat berbeda. Kondisi alam Nduga disebut dengan "terisolasi", "rawan", "berbahaya", dan "sedih sekali”. Sedangkan alam Indonesia secara umum diterangkan di video "Jembatan Holtekamp di Teluk Youtefa” dengan kata “... keindahan alam, kekayaan alam, dan keragaman budaya".

\section{Simpulan dan Saran}

Komunikasi politik berperan untuk merangkai sejumlah kepentingan rakyat menjadi interaksi yang dinamis dan memproduksi program-program yang maslahat. Namun, bagi pemimpin tertinggi politik negara, tidak mudah bagi presiden untuk menemukan kata sepakat di dalam periodenya. Oleh karena itu, menggunakan distorsi bahasa sebagai komunikasi politik untuk memuluskan jalannya kerap digunakan.

Presiden Jokowi memiliki program pembangunan infrastruktur untuk wilayah timur Indonesia. Sejumlah pembangunan besar-besaran dilakukan. Pembebasan lahan, negosiasi dengan masyarakat setempat, serta upaya lainnya dilakukan untuk membangun Papua. Untuk menghalau hambatan yang dapat mengagalkan pembangunan, Jokowi Berdasarkan dua video resmi yang dipublikasikan oleh saluran Youtube Kementerian Sekretariat Negara RI dan Joko Widodo mengandung empat distorsi bahasa. Distorsi bahasa sebagai proyek lupa, distorsi bahasa sebagai topeng, distorsi bahasa sebagai representasi, dan distorsi bahasa sebagai ideologi. 
Distorsi bahasa sebagai topeng digunakan dalam perbahasaan oleh Jokowi untuk menjawab motivasi yang mendorongnya untuk berkunjung dan membangun Papua. Jokowi mengungkapkan alasan ia langsung mengunjungi Papua pada satu setengah bulan pertama kepemimpinannya karena selama ini Papua "dilupakan" dan "diabaikan", kalimat eufemisme dari tawaran publik untuk menggunakan istilah "dianak-tirikan". Jokowi menyebutkan bahwa "dianak-tirikan" memiliki kesan "kejem/kejam". Eufemisme adalah ungkapan yang lebih halus sebagai pengganti ungkapan yang dirasakan kasar.

Eufemisme masuk ke dalam kategori distorsi bahasa sebagai topeng. Apabila narasi "Papua -telah- dikesampingkan" disampaikan oleh seorang Presiden, maka pemahaman itu juga akan menjadi pemahaman negara. Dan pemahaman negara akan daerahnya sebagai bagian yang telah "diabaikan" dan "dilupakan", akan menciptakan pemahaman publik secara luas, baik warga negara Indonesia maupun internasional, bahwa selama ini negara telah meng-“abaikan" dan me-“lupakan" Papua.

Distorsi bahasa sebagai proyek lupa ada pada penjelasan Jokowi menggambarkan perjalanan yang harus dilalui untuk sampai ke Nduga. Jokowi kemudian memberikan narasi dalam penggambarannya mengenai Nduga dengan kalimat, “..., di kabupaten Nduga ini aspal satu meter saja tidak ada. Ini lah yang menyebabkan saya sedih sekali, ...”. Jokowi membangun apa yang disebut oleh Nasution dengan bahasa sebagai proyek lupa. Bahasa sebagai proyek lupa dalam kaitannya dengan komunikasi politik ketika komunikator mengajak gagasan komunikan dalam keadaan lupa, dengan sengaja menghilangkan dan mengecilkan aspek lainnya yang bagi komunikator hendak dianggap tidak penting.

Kata "rawan" dan "berbahaya" yang disampaikan Jokowi yang dirujuk dari Kapolri dan Panglima dalam konteks komunikasi politik dapat bermakna distorsi bahasa sebagai representasi. Kegagalan komunikan memahami maksud komunikator bisa terjadi apabila terjadi distorsi bahasa yang menggambarkan tidak sebagaimana mestinya keadaan. Penggambaran yang tidak sesuai merupakan tindakan yang berbahaya. Penggambaran yang buruk akan suatu hal yang tidak seperti kenyataannya adalah senjata simbolik untuk menghancurkan objek dengan membangkitkan kebencian serta mengesahkan untuk melalukukan pembantaian dan penghancuran, dalam konteks ini adalah OPM dan hal yang membuat Nduga menjadi "rawan" dan "berbahaya".

Distorsi bahasa dalam narasi Jokowi selanjutnya yang berbunyi "Sebuah tugas yang besar dan menantang tapi keadilan sosial adalah sebuah panggilan, adalah kewajiban yang harus dihadirkan negara."Sila ke-lima Pancasila dikutip dalam landasan pembangunan Jokowi dijadikan sebagai ideologi pembangunan. John Rawls memandang keadilan sosial lebih unggul atas teori utilitarianisme, keadilan dilihat apabila memaksimalkan keuntungan dan kegunaan, menggunakan pertimbangan moral etis atas keadilan sosial. Keadilan sosial yang dimaknai Jokowi menggunakan perspektif 
utilitarianisme yang membuat "rata-rata" atau average utulitarianisme dengan memaksimalkan keuntungan rata-rata perkapita.

Narasi Jokowi pada video ini merupakan distorsi bahasa sebagai ideologi. Ideologi pada dasarnya bersifat distorsif, dan distorsi bahasa sebagai ideologi menghendaki narasi distorsi bahasa yang lain. Tujuan dari sifat distorsif dalam mengkomunikasikan ideologi untuk mengidentikkan kegiatan politik sebagai kemampuan politik seorang pemimpin negara dan menawarkan suatu sistem (program) politik tertinggi.

Tujuan penggunaan distorsi bahasa oleh Jokowi adalah agar khalayak mengetahui tujuan dan makna dari program pembangunan yang ia canangkan serta dapat dipahami dan menjadi maklum atas segala dampak yang diakibatkan daripada hal itu. Jokowi dengan secara terbuka menarasikan kepada masyarakat mengenai ideologinya yang penting untuk menjadi pegangan masyarakat dan pemerintah daerah agar ikut mendukung segala upaya yang dilakukan, termasuk pembebasan lahan, membuka jalur hutan, dan sebagainya.

Sebagai upaya melanggengkan kebijakannya, dalam narasinya, Jokowi mengesampingkan mengenai aspek penting yang-lain selain ideologinya. Kenyataan yang terjadi dalam realitas belakangan juga menunjukkan bahwa terdapat sinisme yang dinarasikan secara halus dan tertutup. Upaya elit untuk mempengaruhi masyarakat agar gagasan politik yang memiliki substansi ideologi, orientasi politik dan pemikiran yang diarahkan untuk mempengaruhi masyarakat pada suatu capaian dan prestasi tertentu dengan segala konsekuensi yang patut diperhitungkan, dapatlah disebut sebagai ruang lingkup atau definisi komunikasi politik.

\section{Daftar Pustaka}

Elmslie, Jim. 2003. Irian Jaya Under the Gun: Indonesian Economic Development versus West Papuans Nationalism. Tesis, University of Hawaii Press

Erari, Karel Phil. 2000. Reformata: Indonesia dirobek-robek. Jakarta.

Moleong, Lexy J. 2017. Metodologi Penelitian Kualitatif. Bandung: Rosda Karya

Nasution, Zahri. 2007. Bahasa sebagai Alat Komunikasi Politik dalam Rangka Mempertahankan Kekuasaan. Sodality: Jurnal Transdisiplin Sosiologi, Komunikasi, dan Ekologi Manusia.

Nimmo, Dan. 2010. Komunikasi Politik: Khalayak dan Efek. Bandung: Rosda Karya

Rakhmat, Jalaluddin dan Ibrahim, Idi Subandy. 2015. Metode Penelitian Komunikasi. Jakarta: Simbiosa Rekatama Media

Tarigan, Andi. 2017. Tumpuan Keadilan Rawls. Jakarta: Gramedia

Yudi, Latif., et.al. 1996. Bahasa dan Kekuasaan. Jakarta: ATF Press

Article of Website

"Nduga Zona Merah yang Pernah Dikunjungi Jokowi Saat Resmikan Trans-

Papua".https://www.liputan6.com/news/r ead/3798691/nduga-zona-merah-yangpernah-dikunjungi-jokowi-saat-resmikantrans-papua. Dikunjungi pada 25 Januari 2020

"Nduga Kabupaten yang Tak Semerah Status Kerawanannya".

https://nasional.kompas.com/read/2016/0 1/04/18311151/Nduga.Kabupaten.yang.T ak.Semerah.Status.Kerawanannya diakses pada 25 Januari 2020.

"Profil Kabupaten Nduga". https://pariwisata.papua.go.id/kabupaten/ nduga diakses pada 25 Januari 2020. 